\title{
The potential of LC-MS technique in direct analysis of perfume content
}

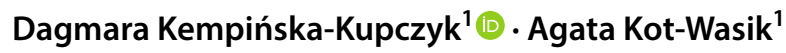

Received: 28 February 2019 / Revised: 8 June 2019 / Accepted: 17 June 2019 / Published online: 14 August 2019

(c) The Author(s) 2019

\begin{abstract}
Perfumes are products that consist of a wide range of natural and synthetic compounds. Due to complex composition, the determination of their ingredients is a difficult task. Most of the perfume components are either volatile or semi-volatile; however, most of the attention has been paid to volatile ones, and thus, gas chromatography or electronic noses are generally used. Nevertheless, in this study, liquid chromatography coupled with mass spectrometry has been applied for direct perfume analysis. Four samples of different best-selling perfumes (two men's and two women's fragrances) and their counterfeits were taken under consideration. The identification of their ingredients was performed by combining obtained results with information available in on-line databases. Compounds specific to essential oils and carrier oils, antioxidants and dyes were generally detected in both types of samples, whereas components of the fragrance of animal origin were only found in brandname perfumes. On the other hand, counterfeits contained more types of polymer emulsifiers. Therefore, based on the results obtained, it can be concluded that liquid chromatography coupled with very sensitive detection technique can be used as a complementary approach to analyses performed with gas chromatography. Moreover, this technique offers the possibility to determine compounds that have low thermostability.
\end{abstract}

\section{Graphic abstract}

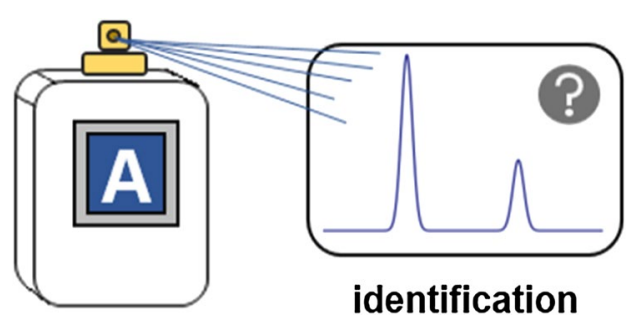

Keywords Dyes · Fragrance notes $\cdot$ High-pressure liquid chromatography $\cdot$ Mass spectrometry $\cdot$ Perfume

\section{Introduction}

Perfume is a mixture of components such as essentials oils, solvents, fixatives, and modifiers, which enable to gain long lasting, agreeable, and desirable scent [1]. Due to the different content of aroma compounds in perfumery products, there are generally classified as extrait de parfum (ca. 20\%),

Dagmara Kempińska-Kupczyk

dagkempi@student.pg.edu.pl

1 Department of Analytical Chemistry, Faculty of Chemistry, Gdańsk University of Technology, Gdańsk, Poland eau de parfum (ca. 15\%), eau de toilette (ca. 10\%), eau de cologne (ca. 5\%), and eau fraiche (ca. 3\%) [2]. Currently, these products are considered as a crucial part of human life [3]. Therefore, it is estimated that the perfume industry is worth over 1 billion USD [4]. In contrast to legal sources of perfumery products, black market offers counterfeits of brand-name cosmetics at lower prices [1]. This illegal, international practice is detrimental not only for perfumery business but also for customers that face the risk of being exposed to mixtures, which may contain hazardous compounds [5]. As a consequence, the risk of allergy induced by some perfume ingredients is still being the subject of 
scientific debate [3]. Moreover, due to their potential negative effects, they present a growing threat to the environment [6].

Considering that perfumes are complex mixtures of various compounds, the determination of their composition is not an easy task. Therefore, their analysis requires advanced and hyphenated techniques [4]. Gas chromatography coupled with mass spectrometry (GC-MS) is the most important tool for qualitative and quantitative analyses of perfume ingredients [3, 4, 7, 8]. In addition to studies on the composition of perfumes and their stability, latest literature shows the potential of GC-MS for the identification of traces of fragrance volatile organic compounds (VOCs) on clothes of a sexual assault victim or other crime scenes. Due to the close distance between the victim and the attacker, fragrances may transfer between them, so that VOCs can provide valuable information in forensic reconstruction [9-11]. Perfume counterfeiting can be also verified based on GC-MS as well as an electronic nose (E-nose) analysis. Moreover, E-noses can be applied for perfume quality assessment [1, 12]. However, various other techniques can be used for this purpose. For instance, Raman spectroscopy has been applied for fragrance content determination [13], whereas the use of easy ambient sonic-spray ionization mass spectrometry (EASIMS) has been shown in perfume fingerprinting [5]. Nevertheless, some perfume ingredients are non-volatile and have low thermostability. In such cases, liquid chromatography coupled with mass spectrometry (LC-MS) can be applied [12]. So far, LC approaches have been focused mainly on the determination of specific perfume ingredients [14-16]. For that reason, the aim of this study was to present the potential of LC-MS technique in direct analysis of the composition of brand-name perfumes and their counterfeits. Therefore, two different types of LC modes were performed and compared. Finally, the examples of compounds detected in perfume samples were presented.

\section{Results and discussion}

The samples of perfumes (A, B, C, and D) and their counterfeits $\left(\mathrm{A}^{\prime}, \mathrm{B}^{\prime}, \mathrm{C}^{\prime}\right.$, and $\left.\mathrm{D}^{\prime}\right)$ have been analyzed using highperformance liquid chromatography coupled with quadrupole-time-of-flight mass spectrometry (HPLC-Q-ToF-MS). During the analyses, HPLC-Q-ToF-MS system was working in scanning mode (SCAN), and the source of electrospray ionization was operating in positive $(\operatorname{ESI}(+))$ and negative (ESI (-)) mode. To obtain the best results, two different approaches have been applied. The first one was based on reversed-phase liquid chromatography (RP-LC) and dedicated to the analysis of hydrophobic compounds, whereas the second one was based on hydrophilic interaction chromatography (HILIC) and used for the detection of polar compounds. In case of RP-LC, isocratic elution mode with $100 \%$ ACN containing $0.05 \% \mathrm{HCOOH}$ was applied, whereas a mixture of water and ACN 3:97\% (v/v) with $0.05 \% \mathrm{HCOOH}$ was used in the HILIC mode. Each obtained chromatogram has been processed with Molecular Feature Extraction Mode (MFE) at threshold set at 5000 units. The idea of this procedure was described elsewhere [17]. The proper setting of MFE parameters enabled to reduce the amount of false-positive results. After data processing, list of around 400 chemical compounds detected in each sample was obtained. Based on that, significant differences between HILIC and RP-LC approaches were obtained as well as a distinction between original samples and their counterfeits. The results obtained for samples A and A' (both ESI mode) are shown in Fig. 1. It can be observed that most of compounds detected in both samples were identified in positive ionization mode. Molecular weight compounds up to $500 \mathrm{~g} \mathrm{~mol}^{-1}$ were mostly determined in samples analyzed with both HILIC and RP-LC approaches. A similar situation was observed in case of negative ionization mode.
Fig. 1 The relationship between the number of detected compounds and their molecular weight

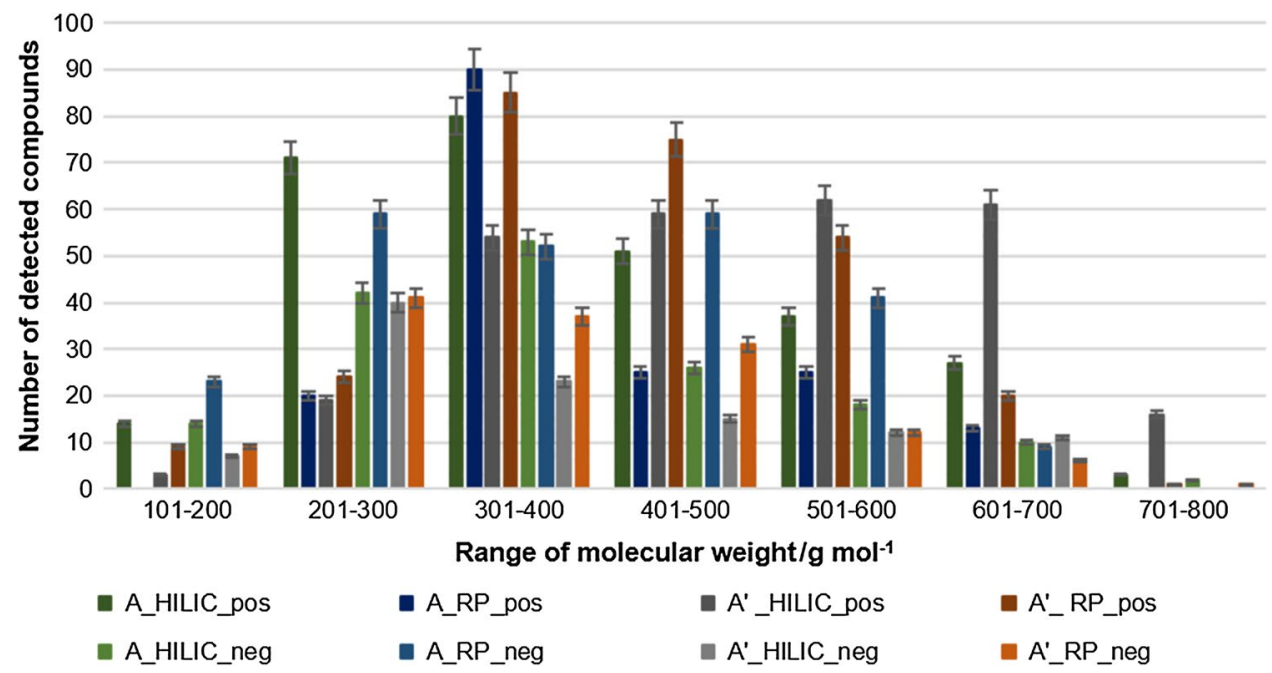


To evaluate the suitability of each approach in perfume analysis, the identification of ingredients was performed by comparing the obtained results with the information available on online databases, according to the following steps: (1) extraction of EIC chromatogram from TIC chromatogram; (2) generation of probable formula of extracted compound; (3) identification in a database; (4) isotope distribution verification of detected compound and comparison with the results from Isotope Distribution Calculator; (5) calculation of mass accuracy between theoretical and experimental $m / z(\Delta \mathrm{ppm}<6)$. First of all, compositions of perfumes that are partially available, were taken under consideration. Since 2003, the manufacturers have been required to provide information about the presence of compounds that may cause contact allergy. Heretofore, 26 fragrance substances have been included in the list of allergens [18]. Subsequently, the obtained results were being searched for components of essential oils used in fragrance notes. Due to the fact that identification of perfume components is difficult and very time-consuming, it was decided to focus on main compounds found in analyzed samples. The results of such evaluation are presented in Table 1.

The use of LC-MS technique enabled to determine compounds from different categories of perfume components (e.g., essential oils, fixatives, or dyes). Pseudomolecular ions characteristic for esters of saturated fatty acids that are ingredients of carrier oils used to dilute essential oils and absolutes were detected in all samples. Carrier oils should be odorless and resistant to oxidation [19], therefore it was assumed that jojoba oil was probably used in the majority of perfume samples. Ambroxide and muscone, compounds specific to fragrances of animal origin, were found in two brand-name perfume (B and C). Due to the limited amount of natural ambergris and musk available on the market, they are quite exclusive products. However, they are used as base notes in perfumery as well as a fixative that holds the fragrance together and regulates the rate of perfume component evaporation [19]. Atranol was detected in both original perfume and counterfeit (A and $\mathrm{A}^{\prime}$ ). This compound is an ingredient of oakmoss essential oil derived from lichen Evernia prunastri. Oakmoss essential oil is generally used in masculine products due to its woody aroma. On the other hand, it is the most frequently reported fragrance that causes contact allergy [18]. Dimethyl benzyl carbinyl butyrate and vanillin were also found in the same sample (A). These compounds are characteristics to plum essential oil (top note component) and vanilla essential oil (base note component), respectively. However, these substances were not found in the counterfeit. Nonetheless, it was expected that the composition of this sample might differ from sample A, due to its very low price and significantly different scent. Vanillin was also detected in samples C and D as well as in their counterfeits. Vanilla essential oil and musk are components of best-selling perfumes of recent years. They are both described as ingredients with aphrodisiac potential and their presence in composition plays a crucial role in buying decision process [8]. Jasmine essential oil is another perfume component that has the same potential. Methyl jasmonate, compound characteristic to this essential oil, was found in samples $\mathrm{C}, \mathrm{C}^{\prime}, \mathrm{D}$, and $\mathrm{D}^{\prime}$. In both cases of original samples, this component was applied to act in the middle note. Moreover, mintlactone was identified in sample $\mathrm{C}$ and $\mathrm{C}^{\prime}$. This fragrance compound, as well as coumarin, can be found in Tonka bean oil. The ingredient of patchouli essential oil (norpatchoulenol) was detected in all samples, with the exception of sample A. However, it was consistent with the fragrance pyramid of this product. Perfume D also contained green coffee seed oil, which was suggested by the detection of vitamin $\mathrm{E}$ [20]. Finally, lilial, a compound found in orange blossom essential oil, was identified in sample B and B'.

Antioxidants are used in perfumery due to the protection of the scent composition of the perfume. Compounds such as avobenzone and diethylamino hydroxybenzoyl hexyl benzoate were detected in original perfumes. Moreover, these compounds protect against oxidation of dyes. Dyes are usually used in consumer products to make them more attractive [16]. In the case of perfume samples analyzed in this work, four different dyes were identified. Sample B contained Acid Red 33, whereas its counterfeit was colorless. This dye was also found in four other samples $\left(C, C^{\prime}, D\right.$, and $\left.D^{\prime}\right)$. Moreover, Sunset Yellow FCF was detected in perfume $\mathrm{C}$ and $\mathrm{C}^{\prime}$ and Brillant Blue FCF was identified in sample D and $\mathrm{D}^{\prime}$. Another dye, Ponceaux SR, was found in almost all original products. It is worth noting that both perfume A and its counterfeit were colorless.

Important perfume ingredients that maintain keeping the composition stable are known as emulsifiers. They enable to mix oil and water-based components and prevent their re-separation. Surfactants are the most commonly used emulsifiers. For this reason, they were also determined in samples. The examples of MS spectra obtained for surfactants are presented in Fig. 2. Due to the presence of a series of oligomeric ions separated by $44 \mathrm{~m} / \mathrm{z}$ units, it was conducted that they belonged to polyethoxylated emulsifiers.

Considering the usefulness of applied analytical approaches, RP-LC-MS technique seems to be more suitable for the determination of perfume components. Most of the identified compounds were generally found in samples analyzed by this technique. Moreover, the use of HILICMS was unsuitable for polymer determination due to lack of the response. It seems that they sorbed irreversibly on HILIC column. 
Table 1 Compounds detected in perfume samples based on HPLC-Q-ToF analysis

\begin{tabular}{|c|c|c|c|c|c|c|c|c|c|}
\hline Compound & Category & $\begin{array}{l}\text { Molecular } \\
\text { formula }\end{array}$ & $\begin{array}{l}\text { Monoiso- } \\
\text { topic mass/g } \\
\mathrm{mol}^{-1}\end{array}$ & $\begin{array}{l}\text { Ionization } \\
\text { mode }\end{array}$ & $\begin{array}{l}\text { Theoretical } \\
m / z\end{array}$ & $\begin{array}{l}\text { Symbol } \\
\text { of sample }\end{array}$ & $\begin{array}{l}\text { Experimental } \\
\mathrm{m} / \mathrm{z}\end{array}$ & Error/ $\Delta \mathrm{ppm}$ & $\begin{array}{l}\text { HPLC } \\
\text { approach }\end{array}$ \\
\hline Acid Red 33 & Dye & $\begin{array}{r}\mathrm{C}_{16} \mathrm{H}_{11} \mathrm{~N}_{3} \\
\mathrm{Na}_{2} \mathrm{O}_{7} \mathrm{~S}_{2}\end{array}$ & 466.9834 & Negative & 443.9936 & $\begin{array}{l}\mathrm{B} \\
\mathrm{C} \\
\mathrm{C}^{\prime} \\
\mathrm{D} \\
\mathrm{D}^{\prime}\end{array}$ & $\begin{array}{l}443.9914 \\
443.9945 \\
443.9920 \\
443.9954 \\
443.9928\end{array}$ & $\begin{array}{r}-4.96 \\
2.03 \\
-3.60 \\
4.05 \\
-1.80\end{array}$ & $\mathrm{RP}$ \\
\hline Ambroxide & $\begin{array}{l}\text { Ambergis } \\
\text { ingredient }\end{array}$ & $\mathrm{C}_{16} \mathrm{H}_{28} \mathrm{O}_{2}$ & 236.2140 & Positive & 237.2213 & $\begin{array}{l}\mathrm{B} \\
\mathrm{C}\end{array}$ & $\begin{array}{l}237.2217 \\
237.2214\end{array}$ & $\begin{array}{l}1.81 \\
0.42\end{array}$ & $\mathrm{RP}$ \\
\hline Atranol & $\begin{array}{c}\text { Essential oil } \\
\text { ingredient }\end{array}$ & $\mathrm{C}_{8} \mathrm{H}_{8} \mathrm{O}_{3}$ & 152.0473 & Negative & 151.0401 & $\begin{array}{l}\mathrm{A} \\
\mathrm{A}^{\prime}\end{array}$ & $\begin{array}{l}151.0410 \\
151.0406\end{array}$ & $\begin{array}{l}5.96 \\
3.31\end{array}$ & $\begin{array}{l}\text { RP and } \\
\text { HILIC }\end{array}$ \\
\hline Avobenzone & Antioxidant & $\mathrm{C}_{20} \mathrm{H}_{22} \mathrm{O}_{3}$ & 310.1569 & Positive & 311.1642 & $\begin{array}{l}\text { B } \\
\text { C } \\
\text { D }\end{array}$ & $\begin{array}{l}311.1636 \\
311.1644 \\
311.1648\end{array}$ & $\begin{array}{r}-1.92 \\
0.64 \\
1.93\end{array}$ & $\begin{array}{l}\text { RP and } \\
\text { HILIC }\end{array}$ \\
\hline $\begin{array}{l}\text { Brillant Blue } \\
\text { FCF }\end{array}$ & Dye & $\begin{array}{c}\mathrm{C}_{37} \mathrm{H}_{34} \mathrm{~N}_{2} \\
\mathrm{Na}_{2} \mathrm{O}_{9} \mathrm{~S}_{3}\end{array}$ & 792.1222 & Negative & 769.1324 & $\mathrm{D}$ & 769.1333 & 1.17 & RP \\
\hline Coumarin & $\begin{array}{c}\text { Essential oil } \\
\text { ingredient }\end{array}$ & $\mathrm{C}_{9} \mathrm{H}_{6} \mathrm{O}_{2}$ & 146.0368 & Positive & 147.0441 & $\begin{array}{l}\mathrm{C} \\
\mathrm{C}^{\prime}\end{array}$ & $\begin{array}{l}147.0437 \\
147.0441\end{array}$ & $\begin{array}{r}-2.72 \\
0.00\end{array}$ & $\mathrm{RP}$ \\
\hline $\begin{array}{l}\text { Dimethyl } \\
\text { benzyl } \\
\text { carbinyl } \\
\text { butyrate }\end{array}$ & $\begin{array}{c}\text { Essential oil } \\
\text { ingredient }\end{array}$ & $\mathrm{C}_{14} \mathrm{H}_{20} \mathrm{O}_{2}$ & 220.1463 & Positive & 221.1536 & A & 221.1537 & 0.45 & $\begin{array}{l}\text { RP and } \\
\text { HILIC }\end{array}$ \\
\hline $\begin{array}{l}\text { Diethylamino } \\
\text { hydroxy- } \\
\text { benzoyl } \\
\text { hexyl } \\
\text { benzoate }\end{array}$ & Antioxidant & $\mathrm{C}_{24} \mathrm{H}_{31} \mathrm{NO}_{4}$ & 397.2253 & Positive & 398.2326 & $\begin{array}{l}\text { A } \\
\text { B }\end{array}$ & $\begin{array}{l}398.2331 \\
398.2322\end{array}$ & $\begin{array}{r}1.26 \\
-1.00\end{array}$ & $\begin{array}{l}\text { RP and } \\
\text { HILIC }\end{array}$ \\
\hline Lilial & $\begin{array}{c}\text { Essential oil } \\
\text { ingredient }\end{array}$ & $\mathrm{C}_{14} \mathrm{H}_{20} \mathrm{O}$ & 204.1514 & Negative & 203.1441 & $\begin{array}{l}\mathrm{B} \\
\mathrm{B}^{\prime}\end{array}$ & $\begin{array}{l}203.1433 \\
203.1447\end{array}$ & $\begin{array}{r}-3.94 \\
2.95\end{array}$ & $\mathrm{RP}$ \\
\hline $\begin{array}{l}\text { Methyl jas- } \\
\text { monate }\end{array}$ & $\begin{array}{c}\text { Essential oil } \\
\text { ingredient }\end{array}$ & $\mathrm{C}_{13} \mathrm{H}_{20} \mathrm{O}_{3}$ & 224.1412 & Positive & 225.1485 & $\begin{array}{l}\mathrm{C} \\
\mathrm{C}^{\prime} \\
\mathrm{D} \\
\mathrm{D}^{\prime}\end{array}$ & $\begin{array}{l}225.1488 \\
225.1486 \\
225.1488 \\
225.1485\end{array}$ & $\begin{array}{l}1.18 \\
0.39 \\
1.33 \\
0.00\end{array}$ & $\mathrm{RP}$ \\
\hline Mintlactone & $\begin{array}{c}\text { Essential oil } \\
\text { ingredient }\end{array}$ & $\mathrm{C}_{10} \mathrm{H}_{14} \mathrm{O}_{2}$ & 166.0994 & Positive & 167.1066 & $\begin{array}{l}\mathrm{C} \\
\mathrm{C}^{\prime}\end{array}$ & $\begin{array}{l}167.1067 \\
167.1064\end{array}$ & $\begin{array}{r}0.56 \\
-1.20\end{array}$ & $\mathrm{RP}$ \\
\hline Muscone & $\begin{array}{l}\text { Musk ingre- } \\
\text { dient }\end{array}$ & $\mathrm{C}_{16} \mathrm{H}_{30} \mathrm{O}$ & 238.2296 & Positive & 239.2369 & $\begin{array}{l}\mathrm{B} \\
\mathrm{C}\end{array}$ & $\begin{array}{l}239.2378 \\
239.2372\end{array}$ & $\begin{array}{l}3.78 \\
1.25\end{array}$ & $\mathrm{RP}$ \\
\hline $\begin{array}{l}\text { Norpatchou- } \\
\text { lenol }\end{array}$ & $\begin{array}{r}\text { Essential oil } \\
\text { ingredient }\end{array}$ & $\mathrm{C}_{14} \mathrm{H}_{22} \mathrm{O}$ & 206.1671 & Positive & 207.1743 & $\begin{array}{l}\mathrm{B} \\
\mathrm{B}^{\prime} \\
\mathrm{C} \\
\mathrm{C}^{\prime} \\
\mathrm{D} \\
\mathrm{D}^{\prime}\end{array}$ & $\begin{array}{l}207.1749 \\
207.1732 \\
207.1753 \\
207.1754 \\
207.1739 \\
207.1745\end{array}$ & $\begin{array}{r}2.90 \\
-5.31 \\
4.83 \\
5.31 \\
-1.93 \\
0.96\end{array}$ & $\begin{array}{l}\text { RP and } \\
\text { HILIC }\end{array}$ \\
\hline $\begin{array}{l}\text { Oleic acid or } \\
\text { its esters }\end{array}$ & $\begin{array}{l}\text { Carrier oil } \\
\text { ingredient }\end{array}$ & $\begin{array}{l}\mathrm{C}_{18} \mathrm{H}_{34} \mathrm{O}_{2} \\
\text { (acid) }\end{array}$ & $\begin{array}{l}282.2559 \\
\quad(\text { acid })\end{array}$ & Negative & 281.2486 & $\begin{array}{l}\mathrm{A} \\
\mathrm{C} \\
\mathrm{C}^{\prime}\end{array}$ & $\begin{array}{l}281.2480 \\
281.2494 \\
281.2491\end{array}$ & $\begin{array}{r}-2.13 \\
2.84 \\
1.78\end{array}$ & $\mathrm{RP}$ \\
\hline
\end{tabular}


Table 1 (continued)

\begin{tabular}{|c|c|c|c|c|c|c|c|c|c|}
\hline Compound & Category & $\begin{array}{l}\text { Molecular } \\
\text { formula }\end{array}$ & $\begin{array}{l}\text { Monoiso- } \\
\text { topic mass/g } \\
\text { mol }^{-1}\end{array}$ & $\begin{array}{l}\text { Ionization } \\
\text { mode }\end{array}$ & $\begin{array}{l}\text { Theoretical } \\
m / z\end{array}$ & $\begin{array}{l}\text { Symbol } \\
\text { of sample }\end{array}$ & $\begin{array}{l}\text { Experimental } \\
\mathrm{m} / \mathrm{z}\end{array}$ & Error/ $\Delta \mathrm{ppm}$ & $\begin{array}{l}\text { HPLC } \\
\text { approach }\end{array}$ \\
\hline \multirow{8}{*}{$\begin{array}{r}\text { Palmitic acid } \\
\text { or its esters }\end{array}$} & \multirow{8}{*}{$\begin{array}{l}\text { Carrier oil } \\
\text { ingredient }\end{array}$} & \multirow{8}{*}{$\begin{array}{l}\mathrm{C}_{16} \mathrm{H}_{32} \mathrm{O}_{2} \\
\text { (acid) }\end{array}$} & \multirow{8}{*}{$\begin{array}{l}256.2402 \\
\text { (acid) }\end{array}$} & \multirow[t]{8}{*}{ Negative } & \multirow[t]{8}{*}{255.2329} & A & 255.2332 & 1.76 & \multirow{8}{*}{$\begin{array}{l}\text { RP and } \\
\text { HILIC }\end{array}$} \\
\hline & & & & & & $\mathrm{A}^{\prime}$ & 255.2339 & 3.92 & \\
\hline & & & & & & B & 255.2337 & 3.13 & \\
\hline & & & & & & $\mathrm{B}^{\prime}$ & 255.2339 & 3.92 & \\
\hline & & & & & & $\mathrm{C}$ & 255.2336 & 2.74 & \\
\hline & & & & & & $\mathrm{C}^{\prime}$ & 255.2338 & 3.53 & \\
\hline & & & & & & $\mathrm{D}$ & 255.2338 & 3.53 & \\
\hline & & & & & & $\mathrm{D}^{\prime}$ & 255.2339 & 3.92 & \\
\hline \multirow[t]{3}{*}{ Ponceaux SR } & \multirow[t]{3}{*}{ Dye } & \multirow{3}{*}{$\begin{array}{r}\mathrm{C}_{18} \mathrm{H}_{14} \mathrm{~N}_{2} \\
\mathrm{Na}_{2} \mathrm{O}_{7} \mathrm{~S}_{2}\end{array}$} & \multirow[t]{3}{*}{480.0038} & \multirow[t]{3}{*}{ Negative } & \multirow[t]{3}{*}{457.0140} & B & 457.0119 & -4.60 & \multirow[t]{3}{*}{$\mathrm{RP}$} \\
\hline & & & & & & $\mathrm{C}$ & 457.0134 & -1.31 & \\
\hline & & & & & & $\mathrm{D}$ & 457.0121 & -4.16 & \\
\hline \multirow{2}{*}{$\begin{array}{l}\text { Sunset Yel- } \\
\text { low FCF }\end{array}$} & \multirow[t]{2}{*}{ Dye } & \multirow{2}{*}{$\begin{array}{r}\mathrm{C}_{16} \mathrm{H}_{10} \mathrm{~N}_{2} \\
\mathrm{Na}_{2} \mathrm{O}_{7} \mathrm{~S}_{2}\end{array}$} & \multirow[t]{2}{*}{451.9725} & \multirow[t]{2}{*}{ Negative } & \multirow[t]{2}{*}{428.9827} & $\mathrm{C}$ & 428.9822 & -1.17 & \multirow[t]{2}{*}{$\mathrm{RP}$} \\
\hline & & & & & & $\mathrm{C}^{\prime}$ & 428.9815 & -2.80 & \\
\hline \multirow{6}{*}{$\begin{array}{l}\text { Stearic acid } \\
\text { or its esters }\end{array}$} & \multirow{6}{*}{$\begin{array}{l}\text { Carrier oil } \\
\text { ingredient }\end{array}$} & \multirow{6}{*}{$\begin{array}{l}\mathrm{C}_{18} \mathrm{H}_{36} \mathrm{O}_{2} \\
\text { (acid) }\end{array}$} & \multirow{6}{*}{$\begin{array}{l}284.2715 \\
\quad(\text { acid })\end{array}$} & \multirow[t]{6}{*}{ Negative } & \multirow[t]{6}{*}{283.2642} & A & 283.2639 & -1.06 & \multirow{6}{*}{$\begin{array}{l}\text { RP and } \\
\text { HILIC }\end{array}$} \\
\hline & & & & & & $\mathrm{A}^{\prime}$ & 283.2653 & 3.88 & \\
\hline & & & & & & B & 283.2650 & 2.82 & \\
\hline & & & & & & $\mathrm{B}^{\prime}$ & 283.2658 & 5.65 & \\
\hline & & & & & & $\mathrm{C}$ & 283.2647 & 1.77 & \\
\hline & & & & & & $\mathrm{C}^{\prime}$ & 283.2648 & 2.12 & \\
\hline \multirow[t]{5}{*}{ Vanillin } & \multirow{5}{*}{$\begin{array}{c}\text { Essential oil } \\
\text { ingredient }\end{array}$} & \multirow[t]{5}{*}{$\mathrm{C}_{8} \mathrm{H}_{8} \mathrm{O}_{3}$} & 152.0473 & Positive & 153.0546 & A & 153.0539 & -4.57 & $\mathrm{RP}$ and \\
\hline & & & & & & $\mathrm{C}$ & 153.0544 & -1.31 & HILIC \\
\hline & & & & & & $\mathrm{C}^{\prime}$ & 153.0539 & -4.57 & \\
\hline & & & & & & $\mathrm{D}$ & 153.0544 & -1.31 & \\
\hline & & & & & & $\mathrm{D}^{\prime}$ & 153.0542 & -2.61 & \\
\hline Vitamin E & $\begin{array}{c}\text { Essential oil } \\
\text { ingredient }\end{array}$ & $\mathrm{C}_{29} \mathrm{H}_{50} \mathrm{O}_{2}$ & 430.3810 & Negative & 429.3738 & $\mathrm{D}$ & 429.3748 & 2.33 & $\mathrm{RP}$ \\
\hline
\end{tabular}

\section{Conclusion}

The prices of perfumery products are affected by the cost of their production. Due to the usage of fragrances of animal origin or other raw materials that are difficult to obtain, some of the brand-name perfumes are very expensive. Therefore, many counterfeits are reaching the markets, resulting in economic losses and potential human and environmental risk. Most of the compounds that vary original product and counterfeit are commonly detected by GC and GC-MS. However, the potential of LC-MS technique in the direct analysis of perfumes was presented in this study. For this purpose, two different chromatographic modes were applied: HILIC and RP-LC. In both cases, low and medium molecular compounds (from 200 to $500 \mathrm{Da}$ ) were generally determined. Among all, different perfume components that are used as ingredients of base and middle notes were mostly detected. Essential oil ingredients, carrier oils components, fixatives, dyes, emulsifiers, and antioxidants were examples of compounds generally found in samples analyzed with RPHPLC-Q-ToF-MS systems, which means that this approach is more suitable for aroma analysis, therefore, proving that the LC-MS can be used as a complementary technique to GC or GC-MS. Moreover, the use of this approach enables to distinguish original perfume from its counterfeit. Nevertheless, further research on the potential of LC-MS in perfume analysis is still required.

\section{Experimental}

Acetonitrile (HPLC grade) and formic acid (>98\%) were purchased from Merck (Darmstadt, Germany). Acetonitrile (LC-MS grade) was obtained from VWR Chemicals (Radnor, USA) and ultrapure water was prepared using HPL5 system from Hydrolab (Wiślina, Poland). 
Fig. 2 Examples of polyethoxylated emulsifiers MS spectrum obtained for $\mathbf{a}$ counterfeit $\mathrm{A}^{\prime}, \mathbf{b}$ sample B, c sample C (a) $\times 10$

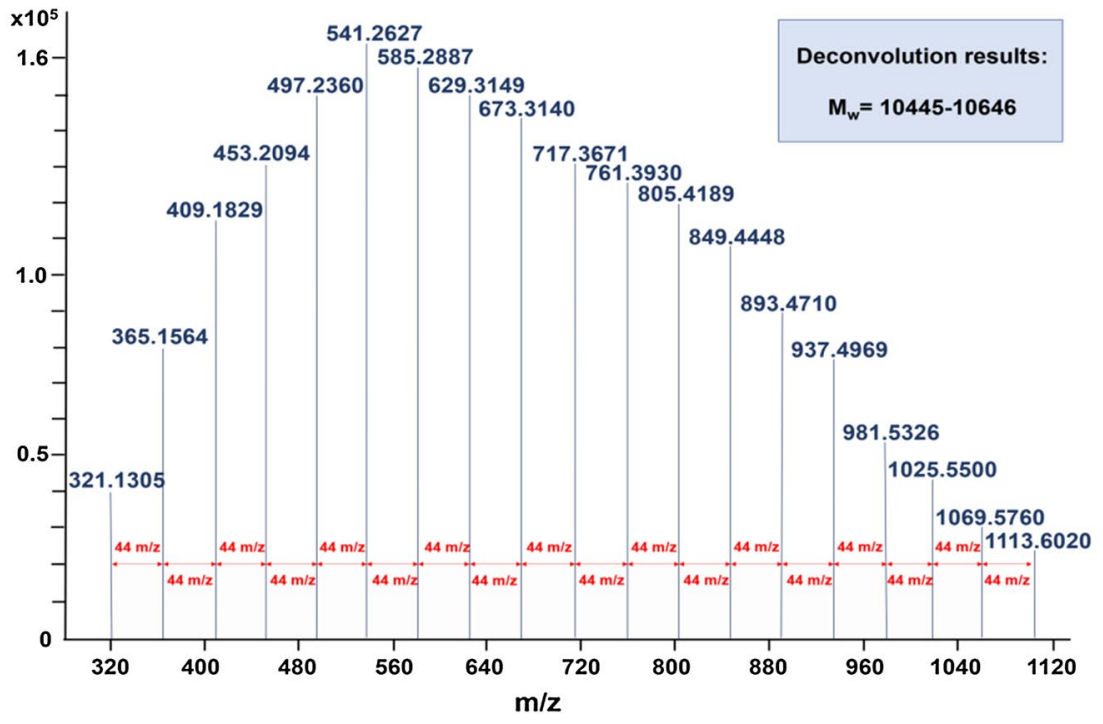

(b)

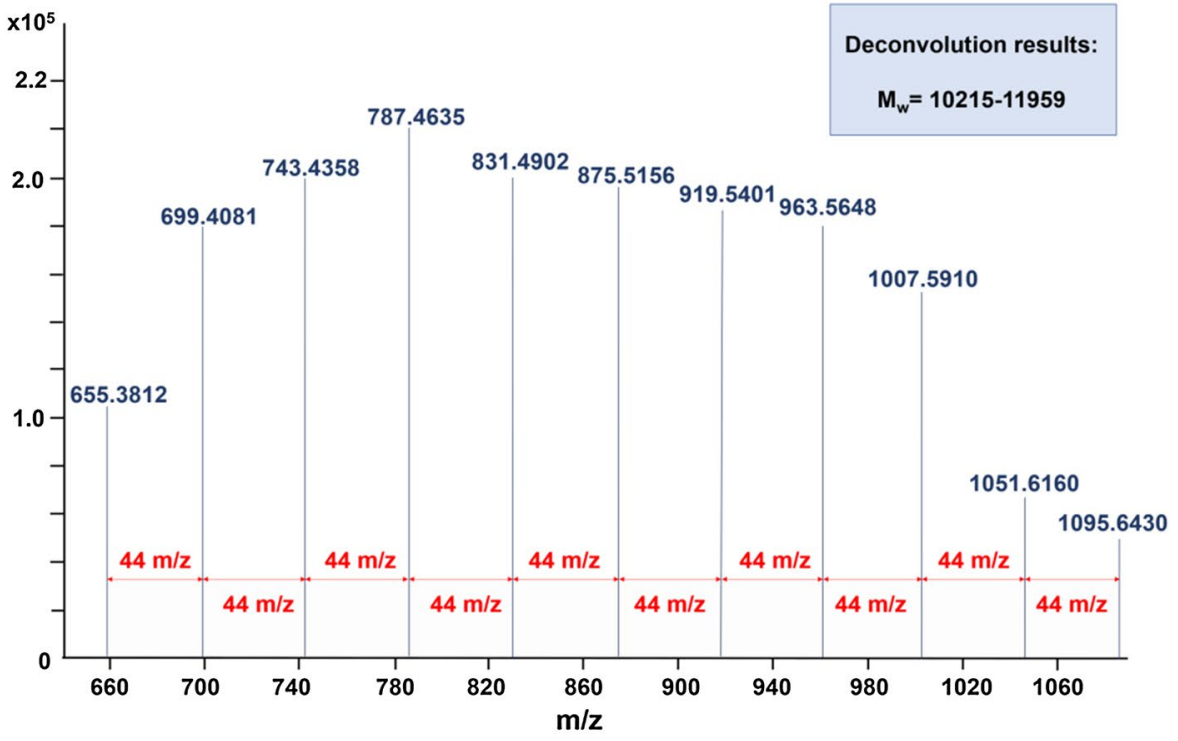

(c) $\times 10$

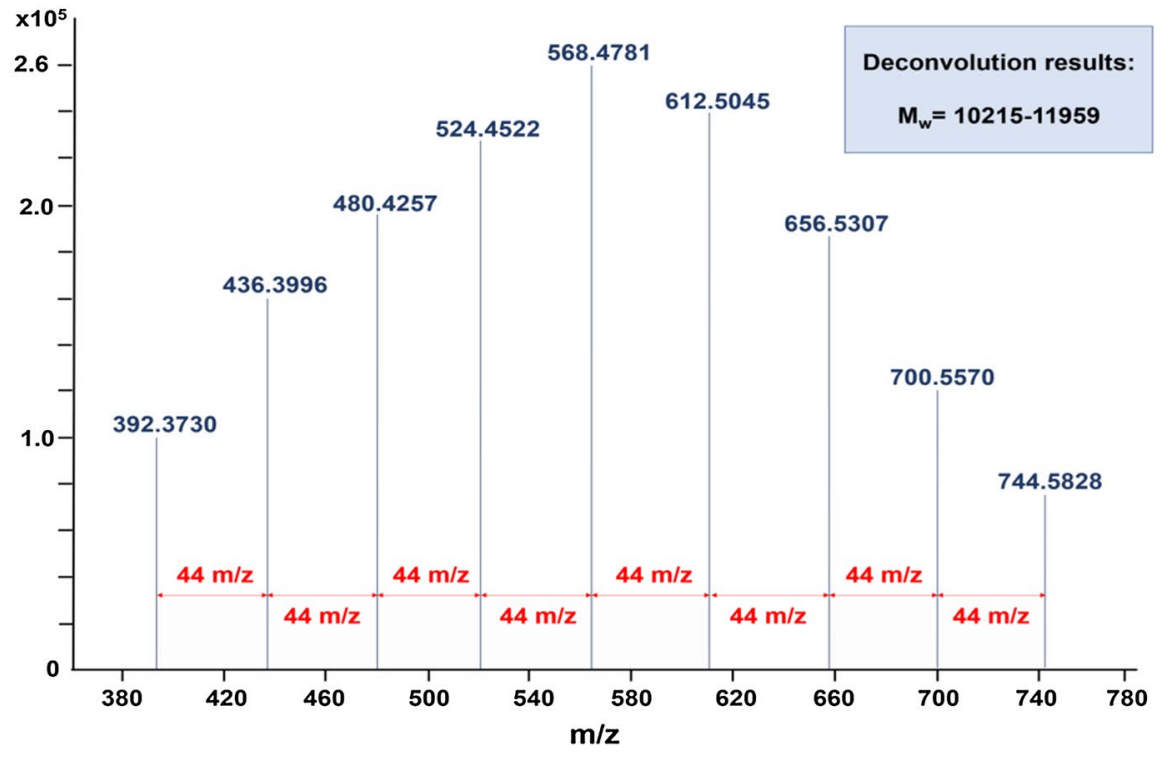




\section{Sampling and sample preparation}

Eight samples of perfume, including brand-name products and their counterfeits, were analyzed. The original ones (two eau de toilette for men and two eau de toilette for women, marked as A, B, C, and D, respectively) were bought in popular perfumery in Gdańsk, whereas their counterfeits were of Chinese origin. The analyzed perfumes differed in fragrance notes. A note of perfume A was woody-oriental, whereas the note of perfume B was wood and spicy. In the case of products for women, the note of perfume $\mathrm{C}$ was oriental and the note of perfume $\mathrm{D}$ was floral and chypre. The manufacturers are not shown due to confidentiality reason.

To prepare samples to analysis, $0.25 \mathrm{~cm}^{3}$ of each brandname and counterfeit perfumes were diluted in $0.25 \mathrm{~cm}^{3}$ of acetonitrile containing $3 \%$ of water. Such prepared samples were injected $\left(20 \mathrm{~mm}^{3}\right)$ directly into the HPLC-Q-TOF-MS system.

\section{Instrumentation}

Both RP-HPLC-Q-TOF-MS and HILIC-Q-TOF-MS analyses were performed using the Agilent 1290 LC system equipped with a binary pump, an online degasser, an autosampler, and a thermostated column compartment coupled with the 6540 Q-TOF-MS with a Dual ESI ion source (Agilent Technologies, Santa Clara, the USA). The ESI source was operated with positive and negative ion ionization mode. The fragmentor voltage was set at $100 \mathrm{~V}$ and the mass range was set at $m / z=100-1500$ in MS. Moreover, a capillary voltage was set at $3500 \mathrm{~V}$, nebulizer gas was set at $35 \mathrm{psi}$, as well as drying gas temperature and flow rate were set at $300{ }^{\circ} \mathrm{C}$ and $10 \mathrm{dm}^{3} / \mathrm{min}$, respectively. The TOF-MS system was calibrated on a daily basis.

In case of RP-HPLC, LiChrospher 100 RP-18e $(125 \times 4 \mathrm{~mm}, 5 \mu \mathrm{m}$; Merck, Darmstadt, Germany) column was used for separation of perfume ingredients. The mobile phase was based on acetonitrile acidified with formic acid $(0.05 \% \mathrm{v} / \mathrm{v})$ and used in isocratic elution mode. The flow rate of mobile phase was $0.8 \mathrm{~cm}^{3} / \mathrm{min}$ and the injection volume was $20 \mathrm{~mm}^{3}$. The column temperature throughout the separation process was kept at $25{ }^{\circ} \mathrm{C}$.

In the case of HILIC, Kinetex HILIC $100 \mathrm{~A}$ $(150 \times 4.6 \mathrm{~mm}, 2.6 \mu \mathrm{m}$; Phenomenex, Torrance, USA) column was used. The acetonitrile and water mixture (97:3 $\mathrm{v} / \mathrm{v})$ with formic acid $(0.05 \% \mathrm{v} / \mathrm{v})$ was applied as a mobile phase. The other chromatographic parameters have been set as above.
Acknowledgements This paper is dedicated to the memory of Prof. Jacek Namieśnik. We are very grateful for his support and advice.

Open Access This article is distributed under the terms of the Creative Commons Attribution 4.0 International License (http://creativeco mmons.org/licenses/by/4.0/), which permits unrestricted use, distribution, and reproduction in any medium, provided you give appropriate credit to the original author(s) and the source, provide a link to the Creative Commons license, and indicate if changes were made.

\section{References}

1. Gębicki J, Szulczyński B, Kamiński M (2015) Meas Sci Technol 26:1

2. Teixeira MA, Rodríguez O, Rodrigues AE (2010) Ind Eng Chem Res 49:11764

3. Mondello L, Casilli A, Tranchida PQ, Dugo G, Dugo P (2005) J Chromatogr A 1067:235

4. van Asten A (2002) TrAC Trends Anal Chem 21:698

5. Haddad R, Catharino RR, Marques LA, Eberlin MN (2008) Rapid Commun Mass Spectrom 22:3662

6. Chen CL, Löfstrand K, Adolfsson-Erici M, MacLeod M (2017) Anal Methods 9:2237

7. Bicchi C, Rubiolo P, Cordero C (2006) Anal Bioanal Chem 384:53

8. Gavriș I, Bodoki E, Verite P, Oprean R (2015) Farmacia 63:760

9. Gherghel S, Morgan RM, Blackman CS, Karu K, Parkin IP (2016) Sci Justice 56:413

10. Gherghel S, Morgan RM, Arrebola-Liébanas J, Romero-González R, Blackman CS, Garrido-Frenich A, Parkin IP (2018) Forensic Sci Int 290:207

11. Gherghel S, Morgan RM, Arrebola-Liébanas JF, Blackman CS, Parkin IP (2019) Sci Justice 53:256

12. Abedi G, Talebpour Z, Jamechenarboo F (2018) TrAC Trends Anal Chem 102:41

13. Godinho RB, Santos MC, Poppi RJ (2016) Spectrochim Acta A $157: 158$

14. Thalhamer B, Himmelsbach M, Buchberger W (2017) Flavour Fragr J 32:46

15. Ramzi A, Ahmadi H, Sadiktsis I, Nilsson U (2018) J Chromatogr A $1566: 102$

16. Guerra E, Celeiro M, Lamas JP, Llompart M, Garcia-Jares C (2015) J Chromatogr A 1415:27

17. Kempińska D, Kot-Wasik A (2018) Monatsh Chem 149:1595

18. Boeye G, Gismera MJ, Sevilla MT, Procopio JR (2017) Electroanalysis 29:116

19. Vankar PS (2004) Resonance 9:30

20. Nosari ABFL, Lima JF, Serra OA, Freitas LAP (2015) Rev Bras Farmacogn 25:307

Publisher's Note Springer Nature remains neutral with regard to jurisdictional claims in published maps and institutional affiliations. 